\title{
Digital Inequality in Theory and Practice: Old and New Divides in the Broadband Era
}

\author{
Luca Cigna \\ Institut drétudes politiques de Paris (Sciences Po) - lucamichele.cigna@sciencespo.fr
}

\begin{abstract}
As of 2017, the number of ICT users worldneeded for benefitting from the ICTs, the wide reached 4 billion people - it was only 16 million in 1995. According to its early observers, the World Wide Web could effectively tackle socio-economic inequalities, promoting the diffusion of information and opportunities on the four corners of the globe. However, despite the expectations, "digital dividends" arising from new technologies have been distributed unevenly, missing the point of a dramatic, wide-spread emancipatory impetus. Furthermore, as the advantaged tend to seize resources and skills deprived could be further "driven out" from the broadband revolution. Building on these concerns, the aim of the paper is that of reviewing the "state of the art" of the digital inequality debate, shedding light on five main accounts: 1 . The adaptive definition of "digital divide"; 2. Methodological approaches; 3. Interaction with other forms of inequalities (socio-economic status, education, race, gender, age); 4. Global dimension and "digital peripheries"; 5. The intrinsically political issue of "connective action".
\end{abstract}

Keywords: Inequality, divide, capital, Internet, broadband

\section{Desigualdade Digital na Teoria e Prática: Antigas e Novas Divisões na Era da Banda Larga}

\section{Sumário}

Resumo: Em 2017, o número de usuários de TIC no mundo atingiu os 4 mil milhões de pessoas - eram apenas 16 milhões em 1995. De acordo com seus primeiros observadores, a World Wide Web poderia efetivamente combater as desigualdades socioeconómicas, promovendo a difusão de informação e oportunidades pelos quatro cantos do globo. No entanto, apesar das expectativas, os "dividendos digitais" decorrentes das novas tecnologias têm sido distribuídos de forma desigual, Passando ao lado de um dramático e generalizado ímpeto emancipatório. Além disso, como os privilegiados tendem a agarrar os recursos e as habilidades necessárias para se beneficiar das TICs, os necessitados podem ser "expulsos" da revolução da banda larga. Com base nestas preocupações, o 
objetivo do artigo é rever o "estado da arte" do debate sobre desigualdade digital, lançando luz sobre cinco pontos principais: 1 . A definição adaptativa de "clivagem digital"; 2. Abordagens metodológicas; 3. Interação com outras formas de desigualdade (status socioeconómico, educação, raça, género, idade); 4. Dimensão global e "periferias digitais"; 5. A questão intrinsecamente política da "ação conectiva".

Palavras-chave: Desigualdade, clivagem, capital, Internet, banda larga

\section{INTRODUCTION}

Invented only in 1989, the World Wide Web can be considered as the most rapidly spreading innovation in recent history. The number of users jumped from 16 million in 1995 to more than 4 billion in 2017 (Internet World Stats, 2018). According to the early observers, its diffusion could reveal a dramatic emancipatory potential: the platform would have promoted informational capital in the geographical and socio-economic peripheries of the globe. However, this revolution has failed to realise: rather than reducing gaps, Information and Communication Technologies may have exacerbated present inequalities, tilting the distribution of new opportunities towards the already advantaged groups. If one third of the world population has some form of online access, the allocation of IT-related resources is still systematically rigged, stressing differences in the way people not only access, but also benefit from internet activities.

In this paper, I review the most important debates around digital divide and digital inequality. In the first section, I briefly describe the theoretical definition of the concept, as well as its evolution in the recent decades. Then, I examine the main methodological approaches. In the following part, I dive into the matter: I analyze its interaction with pre-existing forms of inequality, both on vertical - socio-economic status, education - and horizontal patterns - race, gender, age. Fourthly, I analyze the digital divide in global and comparative terms, accounting for its spatial dimension: are virtual and physical "peripheries" better-off from the IT revolution? In the fifth part, I point out the main political underpinnings, discussing its role in "giving voice the voiceless" (Norris, 2000). Finally, I conclude. 


\section{DIGITAL DIVIDE: AN ADAPTIVE DEFINITION}

Since the 1990s, the introduction of Internet was welcomed with euphoria by the academic and public opinion. The widespread belief that new technologies would have "leveled the playing field", however, came soon to an end: evidence from the US Telecommunication demonstrated that African Americans and rural areas were lagging behind in computer equipment purchase (NTIA, 1995). Scholars began to talk about a "digital divide", describing the gap between the "haves" and "have nots" of the internet revolution (Norris, 2000). The debate was framed in terms of in-out dynamics: those "outside" the digital world should catch up with the insiders of the cyberspace, as subaltern categories (minorities, low-income households) were normatively deemed to fall on the "wrong" side of the divide (Graham, 2011). This perspective resulted to be problematic on three main accounts.

First, the idea that guaranteeing access to new technologies would be sufficient to adjust the unequal distribution of opportunities was fairly simplistic - failing to account for the use that people make of these resources. DiMaggio, Hargittai, Celeste and Shafer (2004) highlighted how the mere access to the internet was by no means explanatory of the benefits arising from IT-based opportunities: if capital endowments determine "first-level" access, indeed, "demand drives intensity of use among people who have access" (DiMaggio et al., 2004). For example, young people were proved to spend more time online than adults, and to use it for a wider range of activities, despite being overall less likely to take access.

Secondly, the old paradigm was ill-suited to discuss situations in which the advantaged make a more efficient use of the resources they receive, which seemed to be the case. The internet, with respect to previous technological advances (as telephones or TVs), required a higher degree of sophistication, demanding users' active involvement; ITC availability by itself would not close existing gaps in skill and capital distribution. According to Min (2010), IT skills, together with political motivation, would be the most robust predictors for explaining a "political" use of the Internet, significantly more than other socio-demographic variables (age, class, gender, race, education).

Finally, "connectivity" was initially thought as a bipolar division between the "connected" and the "disconnected"; nonetheless, it should rather be imagined as a 
continuum, with different forms and degrees of interaction. In this framework, contextual characteristics (politics, economy, institutions, culture) are pivotal to shape the collective definition of the Internet, and the way it is perceived in everyone's lives. Studying the introduction of new technologies in Egyptian classrooms, Warshauer (2003) noted that access to the Internet is just one of the aspects that drive the effective use of ICTs by school pupils. The author advocated for a new understanding of the divide, which would account for the complex, inherently political, process of "coconstitutiveness" between technology and society.

Di Maggio et al.s landmark study (2004) developed a broader framework for digital inequality, encompassing five main elements: 1. Technical means (which replaces the old idea of "access"); 2. "Autonomy of use" (for example, availability of a home computer); 3. "Use patterns" concerning the way the ICTs are used; 4. "Social support networks" that users can rely on; and 5. "Skills" for using technologies. If the "first level" was focused on access, this "second-level" divide would therefore shift the research objectives from detecting the "haves" and the "have nots" to a broader understanding of the "haves much" and the "haves little" (Hilbert, 2011). This "dynamic" definition would allow scholars to study not only current gaps among the population, but more importantly the incremental advantage provided by disruptive innovations: as technological updates were introduced in the market with increasing frequency, "standing still" could easily translate into the "falling behind" for the disconnected (Graham, 2011).

\section{METHODS: THE PUZZLE OF DETECTING DIGITAL INEQUALITY}

Along with the definition of digital divide, research strategies have evolved over time, trying to elucidate the root causes behind digital inequality. The first approach - namely, measuring access rates - was convenient for policymakers. The reasoning went as follows: once access rates across groups and age bands were considered as engendering divides in digital "profits", extending broadband coverage would be sufficient to close the gap. However, this approach did not account for the complexity of the problem (Barzilai-Nahon, 2006). Looking at the "raw" access rates leads to disappointing results, risking to inflate the disadvantage of youth who do not have home computers, or collapsing digital opportunities with actual interest for IT ac- 
tivities (DiMaggio et al., 2004). On this account, different methodologies have been employed to elicit the manifold "angles" of digital inequality.

To begin with, when studying second-level inequality, most scholars employ selfassessment questionnaires, detecting IT habits by means of cross-sectional designs. This approach seems powerful at collecting large amounts of data, describing IT usage distribution across horizontal and vertical characteristics. On the other hand, this measure may lack internal validity for two reasons. Firstly, statistical "noise" might result more difficult to eliminate; second, self-assessment measures could be "pulled" down by a lower perceived self-efficacy. For instance, Hargittai and Shafer (2006) discover that women in their sample tend to underestimate their abilities when coming to online skills. A more appropriate method, hence, could be that of direct abilitytesting: this is the case of van Deursen and van Dijk (2010), who administer capacity tests to survey participants. This approach, though, may suffer from upward ability bias - recording higher-than-expected scores as a result from the "increased" motivation to perform (a sort of Hawtorne effect).

The analysis of digital convergence in IT usage is even more worrisome, often leading to contradictory results. Looking at the relative rate of change in worldwide access among groups, in fact, digital gaps seem to decrease; in absolute terms, however, white males, high-SES and urban users seem to have "outpaced" the other categories (DiMaggio et al., 2004). To come towards this flaw, Martin (2003) proposes to look at odds ratio; using this tool, white people's advantages seem to have fallen until 1997, and then risen in the 1997-2001 period. Similarly, Hilbert (2013) employs a measure of bandwidth flaw - a gradational scale which would determine the distribution of "bites" and "bits" on the local, national and global level. Measuring ICT capacity per individual, he calculates the Gini concentration of digital inequality worldwide, finding out that it has significantly reduced in the last two decades - from 0.64 in 1986 to 0.32 in 2010 . However, what these quantitative designs cannot detect is the quality of Internet use - what Hargittai calls "capital-enhancing activities". At the end of the day, a multi-faceted approach is needed, combining qualitative and quantitative methods to disentangle the profound drivers of digital inequality. 
Digital Inequality in Theory and Practice: Old and New Divides in the Broadband Era

\section{INSIDE THE BLACK BOX: DIGITAL DIVIDE IN PRACTICE}

Despite offering an inexpensive and accessible technology, usage of the internet is strongly associated with socioeconomic status, gender, age, race and educational attainment. These characteristics tend to explain not only access to ICT tools, but also how individuals benefit from them.

\subsection{Vertical inequality and stratification in IT usage}

To begin with, socio-economic background is one of its strongest predictors for online habits. DiMaggio et al. (2004) point out a quasi-linear relationship between the two: $25 \%$ of people with income lower than 15.000 dollars make use of ICTs, while this is the case for $80 \%$ of the over 75.000. For Livingstone and Helsper (2007), this trend is confirmed among younger populations. Studying a sample of British children, they find evidence for both first and second-level divide: having a computer at home remains one of the strongest "explanans" for access to internet; however, middle-class children are more likely to make a "better" use of ICTs, taking up more opportunities for personal enhancement. Accordingly, Robinson (2009) analyses children's approach to the Internet in relation to their socio-economic background. Comparing a rich dataset with in-depth, qualitative interviews, she finds out divergent trends among lower and higher class children: low-income children, who take access from school computers, tend to develop "a taste for the necessary", maturing a goal-oriented approach; by contrast, middle and upper-class children, who often have computers at home, can afford to "play seriously", enhancing their general knowledge by means of an "exploratory stance". According to the author, this kind of "informational habitus" would exacerbate, rather than reduce, digital disadvantage. Zillien and Hargittai (2009) agree with this conclusion; employing a cross-sectional design, they demonstrate that higher SES individuals tend to use Internet for capitalenhancing activities, as reading news, mail usage and making research on travelling, while least well-off use it for "less profitable" tasks.

\subsection{Race: what socioeconomic gaps cannot explain}

Differences among ethnicities have been early noticed in the literature. In general, in the US whites enjoy a higher provision of broadband and computers (US Bureau, 
2018); on the other hand, blacks and Hispanics are more likely to own smartphones, and to use them for meaningful activities, as searching health information or job seeking (Perrin, 2018). DiMaggio et al. (2004) find that, even after controlling for income gaps, a small disadvantage in ICT ownership for the African American remains unexplained, with this gap increasing over time. Campos-Castillo (2012) disagrees with DiMaggio et al's findings: recovering blacks and Latinos' use of the Internet in the last decade, he draws a different story. According to the author, blacks and Latinos did enjoy an increase in terms of access in recent years, but the divide for absolute access has remained constant throughout the decades. Secondly, most studies underscore the intersectional "burden" of race and income: African Americans are twice as likely to be cut off from their internet provision for economic purposes, and less likely to have high-quality connection (Perrin, 2018). To prove this hypothesis, Jackson, Zhao, Kolenic, Fitzgerald, Harold and von Eye (2008) study a sample of 515 US children, comparing their preferences over IT usage. They find that Afro-American children are more likely than white pupils to use the Internet for non capital-enhancing activities; furthermore, their involvement in modern technologies is reported to be a good proxy for academic performance. However, this effect varies along gender lines: Afro-American females benefit most from the internet when compared to other groups, while the opposite seems to be true for Afro-American males.

\subsection{Gender divides: a matter of unequal opportunities}

The existence of a "gendered" divide has been long discussed, and the literature did not come to an agreement. Whereas a usage gap penalized women in the first decade of the internet, it has reduced over time, and today women are reported to use IT devices more than men (Hilbert, 2010). Female users have often been associated with stereotypical images, labelled as less "tech-savvy" and "technophobic". Hargittai and Hinnant (2008) bring empirical evidence to this argument, reporting that women tend to develop lower levels of IT understanding and autonomy of use. According to Hilbert (2010), by contrast, gender bias has reversed: once controlling for employment, education and background, it turns out that women use ICTs more intensely. Therefore, gender divides may rather lay on discriminatory processes in the distribution of digital opportunities. To prove this hypothesis, Livingstone and Helsper (2007) track the interaction between gender and age throughout the early lifetime span: whereas at lower ages no significant gap exists, at 7-8 years old a dis- 
Digital Inequality in Theory and Practice: Old and New Divides in the Broadband Era

crepancy favoring women's access opens up, touching its peak around until 16-17. Yet, if women use internet more ceteris paribus, boys and middle class children are reported to benefit more from IT opportunities, useful to connect with the others and pursue enhancing activities.

\subsection{Age and education: status-related advantage or cumulative experience?}

As a last point, the literature debated about the role of educational attainment and age in determining digital divides. For Hargittai and Hinnant (2008), education explains most of the variance in internet usage; if the age-band between 18 and 24 years old shows the highest connection rates, internet penetration seems to be more effective among college degree-earners and high schoolers. However, educational background ceases to be statistically significant once controlling for respondents' autonomy and experience; therefore, education may simply be a proxy for individual skills. On the other hand, educational attainment seems to be correlated with diverse preferences for online activities, as the less educated are more often in search of jobs. For DiMaggio et al. (2004), the age gap may be reducing throughout the years, showing a convergence in internet habits among groups as these get more involved. Hargittai and Dobranski (2017) partly disconfirm these hypotheses, showing that differentials tend to persist even in older ages: older seniors are less skilled than adults and less eager to pursue capital-enhancing activities. Lastly, van Deursen and van Dijick (2010) try to disentangle the intricate relationship between age, ability, education: the authors administer ability tests to a sample of students; once regressing scores with personal characteristics, education appears to be the most important contributor to internet skills, while age would explain only the ability in "operational" tasks, which in fact relates to experience. Therefore, age premia would not be able to cope with more structural deficits in internet ability, as gathering information and using the Internet for specific goals (strategic skills).

\section{SPATIAL AND GLOBAL DIVIDES: IS THERE ROOM FOR EVERYONE IN THE "GLOBAL VILLAGE"?}

The spatial dimension of digital inequality has been one of the most significant subjects of debate. Already in 2000, Norris foresaw the emancipatory potential of 
new technologies: ICTs could enhance the opportunities of poorer nations, relieving their inhabitants from the burden of anonymity, inability to participate, political marginalization (Norris, 2000). However, acknowledging the risks related to these innovations, she wondered whether it would "strengthen the voice of the voiceless, or produce new forms of inequality". The question seems still relevant.

According to the World Bank (2016), the penetration of technological tools has virtually eliminated first-level divides, as more than half of the world inhabitants enjoy Internet coverage; as of today, more households have access to ICTs than to clean water or electricity. The Bank argues that it is African and Asian "netizens" to benefit more from the Internet, using ICTs for seeking opportunities and important information (health, sanitation, nutrition, etc.). What is problematic, though, is the fact that "digital dividends" (benefits from ICT use) are still biased towards the most advantaged regions, both within and between countries; in 2017, only $35.2 \%$ of Africans and $48.1 \%$ of Asians had some form of online access (Internet World Stats, 2018).

Despite being the first country promoting "Internet inclusion", the US has shown since early times huge divergences in IT distribution, with a consistent gap of around $10 \%$ between rural and metropolitan areas (Strover, Whitacre, Rhinesmith, \& Schrubbe, 2017). Stern, Adams and Elsasser (2009) explore geographic divides in the US, studying gaps in access and use. The authors note that ICTs were first available to wealthiest households, and therefore concentrated in city areas. Drawing on a national telecommunication survey, they find out that rural populations lag behind both for IT access and broadband provision, rarely benefitting from high-quality connection.

Exploring political-economic dimensions, Strover (2014) points out that the US policy for combatting the divide was "episodic" and largely left to be regulated by market forces - which in turn explains why higher prices, connection quality and broadband speed discouraged IT adoption in rural areas. If the quick diffusion of mobile-based Internet access did contribute to reduce this gap, the author remarks how the smartphone "screen size impedes full functionality", insofar as many tasks cannot be performed on the mobile (e.g. job applications, search for opportunities, etc.). Nonetheless, Whitacre, Strover and Gallardo (2014) find evidence for the positive impact of ICTs on employment and income growth in rural areas. According to the scholars, it is broadband adoption, rather than Internet availability, to drive in- 
Digital Inequality in Theory and Practice: Old and New Divides in the Broadband Era

come opportunities for rural US inhabitants. Similarly, Strover et al. (2017) report the beneficial effects of Free Hotspot initiatives promoted by libraries in the rural regions of Maine and Kansas, empowering the rural unskilled with a feeling of "competence" and "competitiveness".

Gaps in digital involvement at the country level are confirmed when looking at international patterns. At the world level, Graham (2011) describes a "digital apartheid", discriminating the "absent" from those who enjoy the online revolution. Guillen and Suarez (2009) frame these global differentials with the Dependency Theory: according to them, broadband distribution would have been concentrated at the Western "core", discriminating the "peripheries" of the globe. They analyze access distribution on a cross-national dataset that account for regulatory, political and social factors in the 1997-2001 period. Results show that GDP per capita still explains most of Internet concentration among countries, followed by privatization and liberalization policies.

Coming to cross-national trends, Hilbert (2013) points out the need of going beyond access-based measures, and looking at broadband capacity: if the number of subscribers per capita has increased by $11 \%$ in the $1986-2010$ period, capacity per capita has risen almost three times as much (31\%). Interestingly, the growth rate in per capita broadband capacity has responded to the introduction of new, disruptive technologies in the world markets. For instance, the introduction of smartphones in 2008-9 provoked a peak in capacity differentials; however, once the costs for these new devices were made accessible to low-income consumers (right after 2010), the digital Gini index fell again. In the longer period, Hilbert depicts a convergence in bandwidth-per-capita distribution. Nonetheless, this trend is mostly driven by the BRICS - while the remaining 156 countries still own less than $26 \%$ of the total ICT capacity.

Moreover, a focus on skill-based divides displays even stronger differentials. Graham (2014) highlights how most of the "production" of digital knowledge is still concentrated in high-income countries; for instance, France produces two times as much of the Wikipedia content as all the African nations together, thereby confuting the hypothesis of a democratic, accessible "open space" of knowledge. Whereas no such databases report the worldwide intensity of Internet usage, differences in "quality" of online activities across world regions are expected to be wide, and possibly increasing. 


\section{A LOGIC OF "CONNECTIVE ACTION": ICTS' ROLE FOR UNMAKING INEQUALITIES}

Apart from promoting individual development, Internet can serve to enhance people's rights, giving to the marginalized an accessible tool for exercising the "voice" option (Hirschman, 1970). Broadband expansion was expected to enable individual freedom, so as their ability to "organize, communicate, distribute information, and participate" (Elliot \& Earl, 2016). However, the situation is more nuanced, as this opportunity may be better capitalized by advantaged groups. In fact, if the privileged are proved to benefit more from what the Web offers, middle and upper classes could be further able to advocate for their needs, ignoring the concerns of those who are "cutout": minority, poor, rural, and politically excluded communities.

Bennet and Segerberg (2012) suggest that the logic of collective action has been recently complemented by a new form of organizing - that of "connective" action. In the past, movements were based on a structured, often hierarchical, understanding of contentious politics, and protests were built on a strong sense of identification. By contrast, web-based mobilizations have shifted to a more "fluid", democratic conception of advocacy. As the author argues, the trait d'union of movements all around the world - from the Arab spring, to the Indignados, passing through Occupy Wall Street - is the individualistic framing of the protests, whereby participants do not belong to groups or organizations. If the collective action in the past was mainly considered as a problem of "common good" - ICT-managed protests have reduced entry barriers to almost zero, contributing to the formation of new cross-class, cross-cultural coalitions.

Despite the clear appeal of this perspective, authors as Elliot and Earl (2016) take a different stance. They lament a fundamental error in the empirical approach: looking exclusively at participants' involvement to exceptional events, these studies would suffer from selection bias, failing to respond to a fundamental question: once access barriers discourage the disadvantaged from participating, do middle and upper-class people engage more online than lower strata? In view of testing this hypothesis, they compare cross-group participation to an online petition. Analyzing online political involvement, they find no significant differences across gender, ethnicity and class. However, these results differ with what found by Schradie (2018): looking at the 
growth of a massive mobilization in North Carolina, the scholar highlights different attitudes in online activism across income groups. She uses both a quantitative comparison (in number of posts, tweets, and likes on social networks) and qualitative strategies (personal interviews). Schradie reports diverse attitudes among groups: on one hand, upper-class organizations tend to share more contents online, making a better use of IT equipment; on the other, working class groups and unions face ability barriers and time constraints; lower-income demonstrators seem to suffer from the invisible "labour cost" of using the social networks, which requires commitment in terms of time, money and effort. These claims are in line with Zillien and Hargittai (2009), for whom low SES interviewees are 33\% less likely to look for political news, and Hargittai and Shaw (2013), that describe how online participation is strongly correlated with offline engagement. Min (2010) agrees with this perspective, and reports that male, white and higher educated citizens use more often the internet for political issues - exploiting what Norris named as "the democratic divide".

\section{CONCLUSION: A LONG WAYTOWARDS DIGITAL EMANCIPATION}

As of 2004, DiMaggio et al. commented the state of research on informational inequality as "severely balkanized". Fourteen years later, the situation has barely changed. Digital divides are reason of discussion not only about their definition, but also on the empirical approach to use; on many accounts, no agreement has been found. However, it is possible to trace some general patterns.

First, access-based divides are sharply declining over time, especially thanks to the introduction of new devices (as smartphones). Second, Internet access may open new opportunities and reduce traditional inequities to some extent (Rains \& Tetsi, 2017); however, it should be acknowledged that "those who function better in the digital realm and participate more fully in digitally mediated social life enjoy advantages over their digitally disadvantaged counterparts" (Robinson, Cotten, Ono, Quan-Haase, Mesch, Chen, Schulz, Hale, \& Stern, 2015). Relevant differences in most countries can still be found across socio-economic status, educational attainment, age and race. The rich, the experienced, the highly educated and white people profit more from Internet consumption, using it for capital and knowledge-enhancing activities. With regards to gender, evidence is inconclusive; nonetheless, old-fashion stereotypes on 
women's aversion towards technologies seem to have been overcome. Fourthly, vertical and horizontal divides are perpetuated along spatial patterns, where the peripheral regions of the world have still to be invested by the web-revolution. Finally, political engagement through the Internet is, as expected, often related to economic and social capital, with the risk of cutting out the "digitally disenfranchised".

All in all, the issue of technological involvement is inherently political. Despite some scholars have argued that the simple abatement of economic barriers, taxes and regulations, may result into enabling more "netizens", the digitally excluded need other forms of empowerment (Norris, 2000); this is signaled by a progressive shift from a "digital divide" to a "digital inclusion" discourse (Strover, 2014). The US is a relevant case study, as most of the dramatic reduction of the first-type divide in the 90s stems from public-policy responses, especially in forms of campaigns and investments (DiMaggio et al., 2004). Insofar as knowledge, self-confidence and IT skills seem to be important catalysts for a virtuous use of digital spaces, policymakers' initiatives should prioritize "digital education" through learning courses and training, enhancing people's awareness about ICT opportunities.

To conclude, Warshauer (2003) is right in arguing that the internet is neither "inherently good or inherently bad. Of course, to complicate matters, neither is the Internet neutral". As this area of research is still in its infancy, efforts should be concentrated to disentangle the complex, multi-faceted issue of digital inequality, ultimately giving it a place in the "twenty-first century pantheon of inequalities" (Robinson et al., 2015). Grounding on serious empirical research, inclusive IT policies could help to bridge the existing divides, making the "Broadband revolution" a useful asset for everybody.

\section{REFERENCES}

Anderson, M. (2018). Digital divide persists even as lower-income Americans make gains in tech adoption. [online] Pew Research Center. Retrieved, May 13, 2018, from http://www.pewresearch.org/fact-tank/2017/03/22/digital-divide-persistseven-as-lower-income-americans-make-gains-in-tech-adoption/ 
Digital Inequality in Theory and Practice: Old and New Divides in the Broadband Era

Barzilai-Nahon, K. (2006). Gaps and Bits: Conceptualizing Measurements for Digital Divide/s. The Information Society, 22(5), 269-278.

Bennett, W., \& Segerberg, A. (2012). The Logic of Connective Action. Information, Communication \& Society, 15(5), 739-768.

US Bureau (2018). The Digital Divide: By Internet, Computer, Race \& Hispanic Origin. [online] Census.gov. Retrieved, May 13, 2018 from https://www.census. gov/library/visualizations/2017/comm/internet.html

Campos-Castillo, C. (2014). Revisiting the First-Level Digital Divide in the United States. Social Science Computer Review, 33(4), 423-439.

DiMaggio, P., Hargittai, E., Celeste, C., \& Shafer, S. (2004). From unequal access to differentiated use: a literature review and agenda for research on digital inequality [report online].

Elliott, T., \& Earl, J. (2016). Online protest participation and the digital divide: Modeling the effect of the digital divide on online petition-signing. New Media \& Society, 20(2), 698-719.

Fairlie, R. (2004). Race and the Digital Divide. Contributions in Economic Analysis \& Policy, 3(1).

Graham, M. (2011). Time machines and virtual portals. Progress in Development Studies, 11(3), 211-227.

Graham, M. (2014). Internet Geographies: Data Shadows and Digital Divisions of Labour. SSRN Electronic Journal.

Guillen, M., \& Suarez, S. (2005). Explaining the Global Digital Divide: Economic, Political and Sociological Drivers of Cross-National Internet Use. Social Forces, 84(2), 681-708.

Hargittai, E., \& Dobransky, K. (2017). Old Dogs, New Clicks: Digital Inequality in Skills and Uses among Older Adults. Canadian Journal of Communication, 42(2).

Hargittai, E. and Hinnant, A. (2008). Digital Inequality. Communication Research, 35(5), 602-621. 
Hargittai, E., \& Shafer, S. (2006). Differences in Actual and Perceived Online Skills: The Role of Gender*. Social Science Quarterly, 87(2), 432-448.

Hargittai, E., \& Shaw, A. (2013). Digitally Savvy Citizenship: The Role of Internet Skills and Engagement in Young Adults' Political Participation around the 2008 Presidential Election. Journal of Broadcasting \& Electronic Media, 57(2), 115134.

Hilbert, M. (2011). Digital gender divide or technologically empowered women in developing countries? A typical case of lies, damned lies, and statistics. Women's Studies International Forum, 34(6), 479-489.

Hilbert, M. (2013). Technological information inequality as an incessantly moving target: The redistribution of information and communication capacities between 1986 and 2010. Journal of the Association for Information Science and Technology, 65(4), 821-835.

Hilbert, M. (2010). When is Cheap, Cheap Enough to Bridge the Digital Divide? Modeling Income Related Structural Challenges of Technology Diffusion in Latin America. World Development, The Multi-Disciplinary International Journal Devoted to the Study and Promotion of World Development, 38(5), 756-770. doi:10.1016/j.worlddev.2009.11.019

Hirschman, A. (1970). Exit, voice and loyalty. Cambridge, Massachusetts: Harvard University Press.

Hsieh, J., Rai, A., \& Keil, M. (2008). Understanding Digital Inequality: Comparing Continued Use Behavioral Models of the Socio-Economically Advantaged and Disadvantaged. MIS Quarterly, 32(1), 97.

Internetworldstats.com. (2018). World Internet Users Statistics and 2018 World Population Stats. [online]. Retrieved, July 18, 2018, from https://www.internetworldstats.com/stats.htm

Jackson, L., Zhao, Y., Kolenic, A., Fitzgerald, H., Harold, R., \& Von Eye, A. (2008). Race, Gender, and Information Technology Use: The New Digital Divide. CyberPsychology \& Behavior, 11(4), 437-442. 
Digital Inequality in Theory and Practice: Old and New Divides in the Broadband Era

Livingstone, S., \& Helsper, E. (2007). Gradations in digital inclusion: children, young people and the digital divide. New media \& society, 9 (4). 671-696.

Martin, S. P. (2003). "Is the Digital Divide Really Closing? A Critique of Inequality Measurementin A Nation Online." IT and Society 1(4, Spring): 1-13.

Min, S. (2010). From the Digital Divide to the Democratic Divide: Internet Skills, Political Interest, and the Second-Level Digital Divide in Political Internet Use. Journal of Information Technology \& Politics, 7(1), 22-35.

Norris, P. (2000). The Worldwide Digital Divide: Information Poverty, the Internet and Development. Paper for the Annual Meeting of the Political Studies Association of the UK, London School of Economics and Political Science.

Ntia.doc.gov. (1995). Falling Through the Net: A Survey of the «Have Nots» in Rural and Urban America | National Telecommunications and Information Administration [online]. Retrieved, May 13, 2018, from https://www.ntia.doc.gov/ntiahome/fallingthru.html

Perrin, A. (2018). Smartphones help blacks, Hispanics bridge some - but not all digital gaps with whites [online]. Pew Research Center. Retrieved, May 13, 2018 , from http://www.pewresearch.org/fact-tank/2017/08/31/smartphones-helpblacks-hispanics-bridge-some-but-not-all-digital-gaps-with-whites/

Rains, S., \& Tsetsi, E. (2016). Social support and digital inequality: Does Internet use magnify or mitigate traditional inequities in support availability?. Communication Monographs, 84(1), 54-74.

Robinson, L. (2009) A Taste for the Necessary. Information, Communication \& Society, 12:4, 488-507.

Robinson, L., Cotten, S. R., Ono, H., Quan-Haase, A., Mesch, G., Chen, W., Schulz, J., Hale, T. M., \& Stern, M. J. (2015) Digital inequalities and why they matter. Information, Communication \& Society, 18:5, 569-582. doi: 10.1080/1369118X.2015.1012532

Schradie, J. (2018). The Digital Activism Gap: How Class and Costs Shape Online Collective Action. Social Problems, 65(1), 51-74. 
Stern, M., Adams, A., \& Elsasser, S. (2009). Digital Inequality and Place: The Effects of Technological Diffusion on Internet Proficiency and Usage across Rural, Suburban, and Urban Counties. Sociological Inquiry, 79(4), 391-417.

Strover, S. (2014) The US Digital Divide: A Call for a New Philosophy. Critical Studies in Media Communication, 31:2, 114-122.

Strover, S., Whitacre, B., Rhinesmith, C., \& Schrubbe, A. (2017). At the Edges of the National Digital Platform. D-Lib Magazine, 23(5/6).

Van Deursen, A., \& van Dijk, J. (2010). Internet skills and the digital divide. New Media \& Society, 13(6), 893-911.

Warschauer, M. (2003). Dissecting the "Digital Divide": A Case Study in Egypt. The Information Society, 19(4), pp.297-304.

Warschauer, M. (2003). Technology and Social Inclusion. Cambridge, MA: MIT Press.

Whitacre, B., Strover, S., \& Gallardo, R. (2014). How Much Does Broadband Infrastructure Matter? Decomposing the Metro Non-Metro Adoption Gap with the Help of the National Broadband Map. SSRN Electronic Journal.

World Bank (2016). World Development Report 2016: Digital Dividends.

Zillien, N., \& Hargittai, E. (2009). Digital Distinction: Status-Specific Types of Internet Usage. Social Science Quarterly, 90(2), 274-291. 